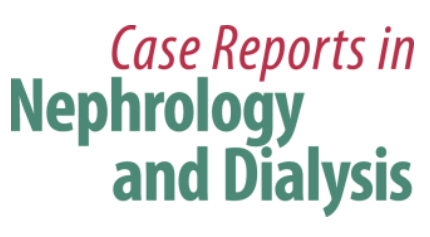

\title{
Use of Leflunomide in Renal Transplant Recipients with Ganciclovir-Resistant/Refractory Cytomegalovirus Infection: A Case Series from the University of Chicago
}

\author{
W. James Chon ${ }^{a}$ Pradeep V. Kadambi ${ }^{\mathrm{e}}$ Chang $\mathrm{Xu}^{\mathrm{a}} \quad$ Yolanda T. Becker ${ }^{\mathrm{b}}$ \\ Piotr Witkowski ${ }^{b} \quad$ Kenneth Pursell ${ }^{c}$ Brenna Kane ${ }^{d}$ \\ Michelle A. Josephson ${ }^{\mathrm{a}}$ \\ Sections of ${ }^{\mathrm{a}}$ Nephrology, ${ }^{\mathrm{b}}$ Transplant Surgery, and ${ }^{\mathrm{c}}$ Infectious Disease, and \\ ${ }^{\mathrm{d}}$ Department of Pharmacy Services, University of Chicago, Chicago, Ill., and ${ }^{\mathrm{e}}$ Division of \\ Nephrology and Transplant Medicine, University of Arizona, Tucson, Ariz., USA
}

Key Words

Renal transplant recipients · Leflunomide · Cytomegalovirus infection

\begin{abstract}
Introduction: Although antiviral prophylaxis for cytomegalovirus (CMV) is widely used, CMV infection remains common in renal transplant recipients with adverse consequences. Methods: We report 5 cases of renal transplant recipients with resistant CMV infection who were successfully managed with leflunomide at the University of Chicago Medical Center. Results: Five renal transplant recipients (2 simultaneous pancreas/kidney transplants, 3 deceased donor kidney transplants) were diagnosed with GCV-resistant CMV infection from 2003 to 2011. Of the 4 patients who had resistance genotype testing, 3 showed a UL97 mutation and 1 patient had a clinically resistant CMV infection. All patients received CMV prophylaxis with valganciclovir for 3 months. The number of days from the date of transplant to viremia ranged from 38 to 458 days (median 219). All 5 patients received other antiviral agents (e.g. ganciclovir, foscarnet), and in 4 patients, viremia was cleared before leflunomide was initiated as consolidation (or maintenance) therapy. Conclusion: Leflunomide was well tolerated and successful in preventing recurrence of viremia in renal transplant recipients with resistant CMV infection. The beneficial effect of leflunomide in this setting warrants further investigation.

(C) 2015 S. Karger AG, Basel
\end{abstract}

KARGER 125/s $\quad \begin{aligned} & \text { W. James Chon, MD } \\ & 5841 \text { S. Maryland Avenue, MC } 5100 \\ & \text { Chicago, IL } 60637 \text { (USA) } \\ & \text { E-Mail wjameschon@uchicago.edu }\end{aligned}$




\section{Case Reports in \\ Nephrology \\ and Dialysis}

Case Rep Nephrol Dial 2015;5:96-105

DOI: $10.1159 / 000381470$

C 2015 S. Karger AG, Basel

www.karger.com/cnd

Chon et al.: Use of Leflunomide in Renal Transplant Recipients with GanciclovirResistant/Refractory Cytomegalovirus Infection

\section{Introduction}

Cytomegalovirus (CMV) is a ubiquitous double-stranded DNA virus that causes significant morbidity and mortality in immunocompromised patients. It is well known for having both direct (viral syndrome, tissue-invasive disease) and indirect effects (increased risk of other opportunistic infections, increased incidence of acute rejection, increased overall mortality) [1]. A systematic review of randomized controlled trials showed that antiviral therapies to prevent CMV disease in solid-organ transplant recipients also reduced mortality [2].

Over the past two decades, advances such as the introduction of CMV nucleic acid amplification testing and the widespread use of CMV prophylaxis have led to an increasing likelihood of viremia detection and disease prevention. On the other hand, issues such as lateonset CMV infection and ganciclovir (GCV)-resistant CMV have become clinically more common. The incidence of late-onset CMV infection has been estimated at 35-40\% when patients are given 3 months of antiviral prophylaxis [3, 4]. The incidence of GCV resistance among high-risk (D+/R-) recipients treated for CMV viremia is in the $5-10 \%$ range $[5,6]$. Other known risk factors associated with developing GCV resistance include the organ transplant type (e.g. lung transplant), prolonged exposure to GCV, subtherapeutic level of GCV, and more potent immunosuppression (such as antithymocyte globulin or OKT-3) [7].

The outcome of the IMPACT trial has led many transplant physicians to extend the duration of CMV prophylaxis in high-risk transplant recipients [3, 8]. Studies have shown that a 6-month course of prophylaxis is cost-effective $[9,10]$. Current guidelines published by the Transplantation Society International CMV Consensus Group recommend that recipients at high risk (D+/R-) receive prophylaxis with 6 months of valganciclovir (VGCV) or are managed with preemptive therapy by monitoring for CMV viremia [11]. Contradictory data and the absence of a large, well-designed head-to-head comparison study make it difficult to draw firm conclusions on the superiority of one regimen over the other [12-17].

Treatments for CMV infection/disease involve a two-pronged approach that includes careful reduction in immunosuppression and the appropriate antiviral medication. However, the risk of acute rejection and side effects of high-dose GCV (e.g. bone marrow suppression) and nephrotoxicity of second-line agents such as foscarnet and cidofovir often limit available options.

Leflunomide is a malononitrileamide whose active metabolite, teriflunomide (formerly known as A77 1726) possesses both antiviral and immunosuppressive properties [18, 19]. Here we describe our successful experience in treating 5 kidney transplant patients with GCV-resistant CMV infection.

\section{Materials and Methods}

This retrospective chart review was approved by the Institutional Review Board of the University of Chicago (IRB protocol \#14-1143). The study included 5 kidney transplant recipients who were treated with leflunomide for CMV infection at the University of Chicago from 2003 to 2011. Patients were informed of the off-label use of leflunomide, and the potential risks, benefits, and alternative options were discussed in detail. The decision to use leflunomide was made by the transplant team and was not a part of a clinical trial.

Standard definitions were used for asymptomatic viremia, CMV syndrome, and tissueinvasive disease [20]. 
Chon et al.: Use of Leflunomide in Renal Transplant Recipients with GanciclovirResistant/Refractory Cytomegalovirus Infection

\section{Clinical Data}

Clinical data were collected including demographic information, donor and recipient CMV serological status, CMV viral load, GCV resistance genotype testing (UL97, UL54), immunosuppressive drug regimen, and other antiviral agents used to treat CMV viremia before and after leflunomide was added to the patients' treatment regimen. Delayed graft function (DGF) was defined as the need for dialysis treatment during the first week after transplant. Relevant posttransplant hospitalization summaries and clinic visit notes were also reviewed.

\section{Immunosuppression}

Patients received either antithymocyte globulin $(1.5 \mathrm{mg} / \mathrm{kg} \times 4-5$ doses $)$ or basiliximab as induction immunosuppressive regimen depending on their immunological risk. Of the 5 patients, 4 were maintained on tacrolimus, mycophenolate mofetil (MMF), and prednisone, and 1 patient was maintained on sirolimus, MMF, and prednisone. When leflunomide was initiated, MMF was discontinued.

\section{Prophylaxis}

All 5 patients were given CMV prophylaxis for at least 3 months. Two patients were given VGCV. For those who received VGCV, the prophylactic dose was $900 \mathrm{mg}$ daily if creatinine clearance $(\mathrm{CrCl})$ was $>60 \mathrm{ml} / \mathrm{min}, 450 \mathrm{mg}$ daily for $\mathrm{CrCl}$ of $40-59 \mathrm{ml} / \mathrm{min}, 450 \mathrm{mg}$ every other day for $\mathrm{CrCl}$ of $25-39 \mathrm{ml} / \mathrm{min}$, and $450 \mathrm{mg}$ twice weekly if $\mathrm{CrCl}$ was $10-24 \mathrm{ml} / \mathrm{min}$. One patient received intravenous (IV) GCV only. The remaining 2 patients were given IV GCV (first 1-2 weeks) followed by oral GCV or VGCV.

\section{Detection Assays}

Until mid-2003, the presence of CMV was detected using CMV DNA hybrid capture assay. Two patients (patients 4 and 5) had parts of their treatment responses monitored in this fashion. The remaining 3 patients had quantitative nucleic acid testing performed when clinically indicated.

\section{Leflunomide Administration}

Patients received a loading dose of $100 \mathrm{mg}$ daily on days 1-5 and were placed on a maintenance dose of $40 \mathrm{mg}$ daily. Teriflunomide levels were not routinely checked unless there were adverse effects of leflunomide such as liver dysfunction.

\section{GCV Resistance Testing}

GCV resistance was suspected if the CMV viral load did not show a decrease by 10-14 days after IV GCV or VGCV was started. Genetic testing for mutations in UL97 and UL54 was performed when GCV resistance was suspected. The testing was performed using polymerase chain reaction (PCR) amplification of CMV DNA followed by gene sequencing (Viromed Laboratories, Minneapolis, Minn., USA).

\section{Results}

\section{Demographic Data}

Table 1 shows the demographic characteristics of the 5 patients ( 3 kidney and 2 kidney/pancreas transplants) who received leflunomide as treatment of GCV-resistant CMV infection. All 5 patients were male and all were African-American except 1 Hispanic patient. CMV serotype matching for 4 transplant recipients was CMV D+/R-, and 1 was CMV D+/R+. 


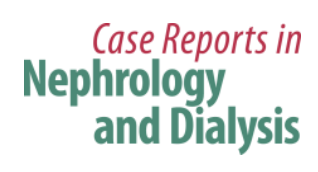

\begin{tabular}{l|l}
\hline \multicolumn{2}{l|}{ Case Rep Nephrol Dial 2015;5:96-105 } \\
\hline DOI: $10.1159 / 000381470$ & $\begin{array}{l}\text { C } 2015 \text { S. Karger AG, Basel } \\
\text { www.karger.com/cnd }\end{array}$ \\
\hline
\end{tabular}

Chon et al.: Use of Leflunomide in Renal Transplant Recipients with GanciclovirResistant/Refractory Cytomegalovirus Infection

\section{Clinical Data}

All 5 patients were considered to be at a high immunological risk for rejection and were given potent immunosuppressive regimens and were at a high risk for opportunistic infections. Patients 2 and 5 were recipients of simultaneous pancreas/kidney transplants (SPK). Patients 3 (third kidney transplant) and 4 were highly sensitized, and patient 4 received a pair of expanded criteria donor (ECD) kidneys. Patient 1 received a retransplanted kidney from a SPK recipient whose postoperative course included treatment for CMV disease with VGCV.

All had received prophylaxis with either IV GCV or oral VGCV for at least 3 months. Two patients (patients 1 and 4) developed CMV viremia while still on VGCV prophylaxis and did not improve when IV GCV was started. IV foscarnet was given until the viral load became undetectable, and then leflunomide was initiated. The remaining patients developed CMV viremia after completion of the viral prophylaxis. The number of days to viremia (from the date of transplant) ranged from 38 to 458 days (median 148 days, mean 219 days).

Fig. 1 shows the response of the viral load to the start of antiviral therapy for the 5 individual patients. All of them had received between 1 and 3 antiviral agents for 2-5 months before leflunomide was started. In all 5 patients, viremia was successfully cleared. Patient 5 died of a myocardial infarction with a functioning allograft. Of the remaining 4 patients, 3 still have functioning renal grafts, while 1 patient who received a paired ECD kidney transplant went back on dialysis 18 months after transplant.

\section{Patient 1}

A 42-year-old African-American male with a history of (h/o) end-stage renal disease (ESRD) of unknown etiology, hypertension (HTN), who was on hemodialysis for 7 years, received a deceased donor renal transplant in July 2005 (fig. 1a). The renal allograft was procured from a 38 year-old Caucasian female who had received a SPK 3 months before (D/R+) and died of intracranial bleed [21]. Her posttransplant course was notable for fever and diarrhea and she was treated with IV GCV for presumed CMV colitis. At the time of the kidney procurement from the first transplant recipient, she was noted to be CMV IgM negative. The second recipient was induced with antithymocyte globulin and received a total of 7 doses in the setting of DGF. His maintenance immunosuppression consisted of tacrolimus, MMF, and prednisone. For CMV prophylaxis, he was given IV GCV (50 mg IV daily for 2 weeks) followed by VGCV (450 mg daily). However, he was found to have leukopenia and CMV viremia on postoperative day (POD) 38 (307,000 copies/ml) while he was still on VGCV. He was switched to IV GCV but his viral load continued to rise, and IV foscarnet (3 gm BID) was started on POD 51. The genetic mutation study was notable for UL97 mutation. Viremia was cleared on POD 72, and IV foscarnet was continued until POD 179. Leflunomide was started on POD 185, and he still remains on it. His renal allograft is still functioning (serum creatinine, Scr 1.7-2.1 mg/dl) 10 years later, and he has not had a recurrence of CMV vire$\mathrm{mia} /$ disease.

\section{Patient 2}

A 34-year-old Hispanic male with h/o ESRD, type 1 diabetes mellitus, HTN, and hyperlipidemia, who was on hemodialysis for 3.5 years, underwent a SPK (D+/R-) in August 2008 (fig. 1b). His induction treatment consisted of daclizumab. He was on tacrolimus, MMF, and prednisone, and there was no DGF. He was given a 3-month course of VGCV for CMV prophylaxis. He developed CMV viremia (67,000 copies/ml) on POD 373 and was symptomatic with malaise and diarrhea. Although he was started on IV GCV treatment, the CMV viral load continued to rise, and IV foscarnet was started on POD 378. The CMV viral load peaked at 


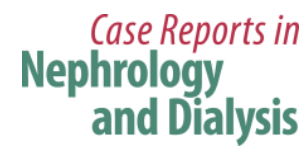

\begin{tabular}{l|l}
\hline Case Rep Nephrol Dial 2015;5:96-105 \\
\hline DOI: $10.1159 / 000381470$ & $\begin{array}{l}\text { C 2015 S. Karger AG, Basel } \\
\text { www.karger.com/cnd }\end{array}$ \\
\hline
\end{tabular}

Chon et al.: Use of Leflunomide in Renal Transplant Recipients with GanciclovirResistant/Refractory Cytomegalovirus Infection

214,000 copies/ml on POD 383, and the virus became undetectable on POD 401. IV foscarnet was discontinued on POD 436. Leflunomide was started on POD 528 and discontinued on POD 1,106 when his liver function tests were found to be elevated [AST 118 (normal range 15-37) and ALT 248 (normal range 8-35)]. A liver biopsy showed steatohepatitis (grade 1, stage 1). A normalization of the liver enzymes was seen 10 weeks after leflunomide was discontinued. The patient has remained free of CMV viremia/disease, and his renal allograft is still functioning (Scr $2.8-3.0 \mathrm{mg} / \mathrm{dl}$ ).

\section{Patient 3}

A 43-year-old, highly sensitized (PRA: Class I 56\%, Class II 85\%) African-American male with h/o of ESRD secondary to posterior urethral valve syndrome, s/p DDRT (06/1987), s/p LRRT (10/1987) underwent a third renal transplant (D+/R-) with an ileal conduit on January 27, 2011 (fig. 1c). He was induced with antithymocyte globulin (100 $\mathrm{mg} \times 4$ doses). He received a 100-day course of VGCV ( $900 \mathrm{mg}$ daily) for CMV prophylaxis. His posttransplant course was complicated by an intra-abdominal abscess requiring surgical drainage and prolonged bowel rest except for his medications. CMV was first detected on POD 146 when the patient presented with diarrhea and weakness. He was treated with VCGV (900 mg BID) but continued to have low-grade viremia for the next 5 months. UL97 mutation was detected, and leflunomide was started on POD 297. An investigational oral analogue of cidofovir (CMX001, now known as brincidofovir) obtained from Chimerix for compassionate use was added on POD 322 and discontinued on POD 439. The patient's renal allograft function remains stable (Scr of 1.3-1.4 mg/dl), and he continues on leflunomide.

\section{Patient 4}

A 45-year-old, highly sensitized (PRA 88-100\%) African-American male with h/o of ESRD of unknown etiology, HTN, who was on hemodialysis for 7 years, received a paired deceased donor kidney transplant from a 67-year-old deceased donor in December 2002 (fig. 1d). He received 1 dose of antithymocyte globulin and 2 doses of basiliximab for induction. His posttransplant course was complicated by DGF. He received VGCV for CMV prophylaxis but developed leukopenia and CMV viremia while still on VGCV prophylaxis on POD 80. He was treated with an increased dose of VGCV and was switched to IV GCV treatment on POD 110 when the CMV DNA hybrid capture test results continued to rise. Foscarnet was started on POD 134, and CMV was undetectable on POD 154, at which time foscarnet was replaced with leflunomide. There was no recurrence of CMV viremia/disease, but the patient had gradually worsening renal allograft function. A renal biopsy on POD 145 showed acute tubulointerstitial nephritis (due to foscarnet), and a subsequent biopsy on POD 318 showed a type $1 \mathrm{~A}$ rejection and chronic allograft nephropathy with $40 \%$ tubular loss. He was restarted on dialysis in July 2004.

\section{Patient 5}

A 51-year-old African-American male with h/o of ESRD, type 1 DM, and HTN underwent a SPK in May 2001 (fig. 1e). He was induced with 1 dose of antithymocyte globulin and 2 doses of basiliximab and was maintained on sirolimus/MMF/prednisone. His CMV prophylaxis consisted of 3 months of GCV treatment (mostly IV). His posttransplant course was complicated by DGF and three episodes of acute rejection (two type 1B rejections (on POD 21 and 43 ) and one type 2A rejection (on POD 184) and required treatment with IV antithymocyte globulin as well as pulse steroids. Viremia, first detected on POD 458, was accompanied by diarrhea and malaise, and the patient was treated with IV GCV. Although his viral load improved as estimated by a CMV hybrid capture study, he was unable to eradicate the 


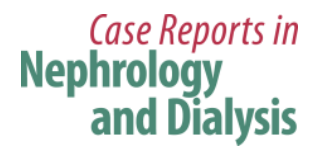

\begin{tabular}{l|l}
\hline \multicolumn{2}{l|}{ Case Rep Nephrol Dial 2015;5:96-105 } \\
\hline DOI: $10.1159 / 000381470$ & $\begin{array}{l}\text { C } 2015 \text { S. Karger AG, Basel } \\
\text { www.karger.com/cnd }\end{array}$ \\
\hline
\end{tabular}

Chon et al.: Use of Leflunomide in Renal Transplant Recipients with GanciclovirResistant/Refractory Cytomegalovirus Infection

viremia, and a 2-week course of IV foscarnet was started on POD 595 to achieve viral clearance. He had a recurrence of CMV viremia on POD 811 and was treated with IV GCV but without viral clearance. IV foscarnet was started on POD 884, and leflunomide was added on POD 942. His last detectable CMV viremia occurred on POD 1,420. He died on POD 3,359 of a myocardial infarction. His renal allograft function ranged from $1.7-2.0 \mathrm{mg} / \mathrm{dl}$ in the last 3 months of his life.

\section{Discussion}

Since leflunomide received FDA approval in 1998 for the use in treating rheumatoid arthritis, its potential use as an antiviral agent has been explored by several groups $[18,19]$. Its known mechanisms of action include inhibition of the enzyme dihydroorotate dehydrogenase and inhibition of phosphorylation of tyrosine kinases involved in T- and B-cell activity. Leflunomide is unique in that it appears to possess both immunosuppressive and antiviral properties [19].

Unlike other antiviral drugs that inhibit the viral DNA polymerase, leflunomide seems to act by preventing tegument acquisition by viral nucleocapsids. This unique mechanism of action makes it a potentially useful candidate drug in treating GCV-resistant CMV.

Reduction of immunosuppression is an important component of antiviral treatment in renal transplant recipients; however, the concern for precipitating an acute rejection episode often limits this option. Although not tested in the patients described in this series, replacing MMF with a mTOR inhibitor is another potential strategy to be considered. Several observation studies have suggested that sirolimus or everolimus may be associated with a lower incidence of CMV disease [22, 23].

Most cases of GCV resistance stem from mutations in the phosphotransferase gene (UL97) or in the DNA polymerase gene (UL54). Use of more potent induction and/or maintenance immunosuppressive agents and routine prophylaxis using oral GCV are thought to contribute to the development of a GCV-resistant CMV strain. In addition, underdosing of GCV when using estimated GFR or using the ideal body weight in the CockcroftGault formula when calculating $\mathrm{CrCl}$ in obese patients is likely to result in a subtherapeutic level of GCV [24, 25].

We described a series of 5 renal transplant recipients who had GCV-resistant CMV disease (3 of 5 with UL97 mutations) and were successfully managed with leflunomide-based 'consolidation' therapy. Our strategy for treating GCV-resistant CMV in renal transplant recipients was to achieve viral clearance with IV foscarnet and maintain suppression of viral replication using leflunomide, which does not cause nephrotoxicity. In four cases, viral clearance was achieved with IV foscarnet and leflunomide was initiated to prevent viral recurrence. In 1 case, the patient had low-level viremia with first-line therapy (IV GCV or VGCV) and leflunomide was given with another oral agent (CMX001/brincidofovir) in order to achieve clearance of viremia.

The efficacy and safety of leflunomide as an antiviral agent have not been studied thoroughly. Farasati et al. [26] considered the antiviral effect of leflunomide against BK virus to be moderate at best based on a low selectivity index value of 3.8. As an anti-CMV agent, leflunomide lacks pharmacodynamic data including $50 \%$ effective concentration $\left(\mathrm{EC}_{50}\right)$ and selectivity index and has a wide interpatient variability in pharmacokinetics $[27,28]$. In the clinical setting of high-grade viremia, it has been reported not to be very effective [29]. Taking this into consideration, we decided to achieve viral clearance with foscarnet and prevent viral recurrence with leflunomide. Reported adverse effects include diarrhea, anemia, trans- 


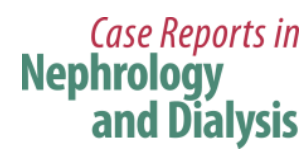

\begin{tabular}{l|l}
\hline \multicolumn{2}{l}{ Case Rep Nephrol Dial 2015;5:96-105 } \\
\hline DOI: 10.1159/000381470 & $\begin{array}{l}\text { ○ 2015 S. Karger AG, Basel } \\
\text { www.karger.com/cnd }\end{array}$ \\
\hline
\end{tabular}

Chon et al:: Use of Leflunomide in Renal Transplant Recipients with GanciclovirResistant/Refractory Cytomegalovirus Infection

aminitis, peripheral neuropathy, and thrombotic microangiopathy. We did not observe any of the known adverse effects except abnormal liver function tests (patient 2). In light of the long half-life of teriflunomide ( 15 days), it may take several weeks for liver function tests to return to normal after discontinuation of the drug. In our experience, leflunomide is well tolerated and effective in preventing viral recurrence when used with short-term foscarnet in treating GCV-resistant CMV infection.

A review of the literature on the use of leflunomide in renal transplant recipients with CMV infection revealed only six publications, all of them case reports (table 2). Although the majority of the publications report clinical success, this could be attributed to reporting bias. Recently, a case report of failure of leflunomide to control recurrent CMV in an allogeneic stem cell transplant recipient has been reported [30]. A close look at the report shows that the patient was given leflunomide for only 2 weeks. In light of its long half-life, it is unlikely that the patient would have achieved a reasonable steady state during that time period.

In conclusion, leflunomide is a unique agent that possesses both antiviral and immunosuppressive properties. It may be useful in managing GCV-resistant CMV and deserves further study to confirm our findings and to determine the ideal dose and duration of the treatment.

\section{Disclosure Statement}

The authors declare that there are no conflicts of interests regarding the publication of this paper.

\section{References}

$>1$ Kotton CN: Management of cytomegalovirus infection in solid organ transplantation. Nat Rev Nephrol 2010;6:711-721.

-2 Hodson EM, Jones CA, Webster AC, Strippoli GFM, Barclay PG, Kable K, Vimalachandra D, Craig JC: Antiviral medications to prevent cytomegalovirus disease and early death in recipients of solid-organ transplants: a systemic review of randomized controlled trials. Lancet 2005;365:2105-2115.

-3 Humar A, Lebranchu Y, Vincenti F, Blumberg EA, Punch JD, Limaye AP, Abramowicz D, Jardine AG, Voulgari AT, Ives J, Hauser A, Peeters P: The efficacy and safety of 200 days valganciclovir cytomegalovirus prophylaxis in high-risk kidney transplant recipients. Am J Transplant 2010;10:1228-1237.

-4 Helantera I, Kyllonen L, Lautenschlager I, Salmela K, Koshinen P: Primary CMV infections are common in kidney transplant recipients after six months valganciclovir prophylaxis. Am J Transplant 2010;10:20262032.

5 Eid AJ, Arthurs SK, Deziel PJ, Wilhelm MP, Razonable RR: Emergence of drug-resistant cytomegalovirus in the era of valganciclovir prophylaxis: therapeutic implications and outcomes. Clin Transplant 2008;22:162170.

6 Lurain NS, Chou S: Antiviral drug resistance of human cytomegalovirus. Clin Microbiol Rev 2010;23:689712.

7 Limaye AP, Corey L, Koelle DM, Davis CL, Boeckh M: Emergence of ganciclovir-resistant cytomegalovirus disease among recipients of solid-organ transplants. Lancet 2000;356:645-649.

-8 Humar A, Limaye AP, Blumberg EA, Hauser IA, Vincenti F, Jardine AG, Abramowicz D, Ives JAL, Farhan M, Peeters P: Extended valganciclovir prophylaxis in D+/R- kidney transplant recipients is associated with long-term reduction in cytomegalovirus disease: two-year results of the IMPACT study. Transplantation 2010;90:1427-1431.

-9 Luan FL, Stuckey LJ, Park JM, Kaul D, Cibrik D, Ojo A: Six-month prophylaxis is cost effective in transplant patients at high risk for cytomegalovirus infection. J Am Soc Nephrol 2009;20:2449-2458.

-10 Blumberg EA, Hauser IA, Stanisic S, Mueller E, Berenson K, Gahlemann CG, Humar A, Jardine AG: Prolonged prophylaxis with valganciclovir is cost effective in reducing posttransplant cytomegalovirus disease within the United States. Transplantation 2010;90:1420-1426. 
Chon et al.: Use of Leflunomide in Renal Transplant Recipients with Ganciclovir Resistant/Refractory Cytomegalovirus Infection

11 Kotton CN, Kumar D, Caliendo AM, Asberg A, Chou S, Danziger-Isakove L, Humar A: Updated international consensus guidelines on the management of cytomegalovirus in solid-organ transplantation. Transplantation 2013;96:333-360.

12 Kliem V, Fricke L, Wollbrink T, Burg M, Radermacher J, Rohde F: Improvement in long-term renal graft survival due to CMV prophylaxis with oral ganciclovir: results of a randomized clinical trial. Am J Transplant 2008;8:975-983.

13 Reischig T, Hribova P, Indra P, Hes O, Bouda M, Treska V, Viklicky O: Long-term outcomes of preemptive valganciclovir compared with valacyclovir prophylaxis for prevention of cytomegalovirus in renal transplantation. J Am Soc Nephrol 2012;23:1588-1597.

-14 Spinner ML, Saab G, Casabar E, Bowman LJ, Storch GA, Brennan DC: Impact of prophylactic versus preemptive valganciclovir on long-term renal allograft outcomes. Transplantation 2010;90:412-418.

15 Le Page AK, Jager MM, Iwasenko JM, Scott GM, Rawlinson WD: Clinical aspects of cytomegalovirus antiviral resistance in solid organ transplant recipients. Clin Infect Dis 2013;56:1018-1029.

16 Garcia-Ahufinger I, Gutierrez-Aroca J, Cordero E, Vidal E, Cantisan S, del Castillo D, Martin-Gandul C, Rivero A, Torre-Disneros J: Use of high-dose ganciclovir for the treatment of cytomegalovirus replication in solid organ transplant patients with ganciclovir resistance-inducing mutations. Transplantation 2013;95:10151020.

17 Mylonakis E, Kallas WM, Fishman JA: Combination antiviral therapy for ganciclovir-resistant cytomegalovirus infection in solid-organ transplant recipients. Clin Infect Dis 2002;24:1337-1341.

18 Waldman WJ, Knight DA, Blinder L, Shen J, Lurain NS, Miller DM, Sedmak DD, Williams JW, Chong AS: Inhibition of cytomegalovirus in vitro and in vivo by the experimental immunosuppressive agent leflunomide. Intervirology 1999;42:412-418.

19 Chong AS, Zeng H, Knight DA, Shen J, Meister GT, Williams JW, Waldman WJ: Concurrent antiviral and immunosuppressive activities of leflunomide in vivo. Am J Transplant 2006;6:69-75.

20 Ljungman P, Griffiths P, Paya C: Definitions of cytomegalovirus infection and disease in transplant recipients. Clin Infect Dis 2002;73:358-366.

-21 Kadambi PV, Chon WJ, Josephson MA, Desai A, Thistlethwaite JR, Harland RC, Meehan SM, Garfinkel MR: Reuse of a previously transplanted kidney: does success come with a price? Clin Kidney J 2012;5:434-437. Ozaki KS, Camara NO, Nogueira E, Pereira MG, Granato C, Melaragno C, Camargo LFA, Pacheco-Silva A: The use of sirolimus in ganciclovir-resistant cytomegalovirus infections in renal transplant recipients. Clin Transplant 2007;21:675-680.

23 Sabe N, Gonzalez-Costello J, Rama I, Niubo J, Bodro M, Roca J, Cruzado JM, Manito N, Carratala J: Successful outcome of ganciclovir-resistant cytomegalovirus infection in organ transplant recipients after conversion to mTOR inhibitors. Transplant Int 2012;25:e78-e82.

-24 Posadas Salas MA, Taber DJ, Chua E, Pilch N, Chavin K, Thomas B: Critical analysis of valganciclovir dosing and renal function on the development of cytomegalovirus infection in kidney transplantation. Transpl Infect Dis 2013;15:551-558.

-25 Trevillyan J, Angus P, Shelton E, Whitlam J, Ierino F, Pavlovic J, Gregory D, Urbancic K, Torresi J, Testro A, Grayson ML: Electronic estimations of renal function are inaccurate in solid-organ transplant recipients and can result in significant underdosing of prophylactic valganciclovir. Antimicrob Agents Chemother 2013;57:4058-4060. an in vitro culture system. Transplantation 2005;79:116-118. Chako B, John GT: Leflunomide for cytomegalovirus: bench to bedside. Transpl Infect Dis 2011;14:111-120. Williams JW, Mital D, Chong A, Kottayil A, Millis M, Longstreth J, Huang W, Brady L, Jensik S: Experiences with leflunomide in solid organ transplantation. Transplantation 2002;73:358-366.

29 Avery RK, Mossad SB, Poggio E, Lard M, Budev M, Bolwell B, Waldmann WJ, Braun W, Mawhorter SD, Fatica R, Krishnamurthi V, Young JB, Shrestha R, Stephany B, Lurain N, Yen-Lieberman B: Utility of leflunomide in the treatment of complex cytomegalovirus syndromes. Transplantation 2010;90:419-426. Battiwalla M, Paplham P, Almyroudis NG, McCarthy A, Abdelhalim A, Elefante A, Smith P, Becker J, McCarthy PL, Segal BH: Leflunomide failure to control recurrent cytomegalovirus infection in the setting of renal failure after allogeneic stem cell transplantation. Transpl Infect Dis 2007;9:28-32.

-31 Andrassy J, Illner WD, Rentsch M, Jaeger G, Jauch KW, Fischereder M: Leflunomide: a treatment option for ganciclovir-resistant cytomegalovirus infection after renal transplantation. NDT Plus 2009;2:149-151.

-32 Ciszek M, Mucha K, Foroncewicz B, Chmura A, Paczek L: Leflunomide as a rescue treatment in ganciclovirresistant cytomegalovirus infection in a seronegative renal transplant recipient - a case report. Ann Transplant 2014;19:60-63.

33 John GT, Manivannan J, Chandy S, Peter S, Jacob CK: Leflunomide therapy for cytomegalovirus disease in renal allograft recipients. Transplantation 2004;77:1460-1461.

-34 John GT, Manivannan J, Chandy S, Peter S, Fleming DH, Chandy SJ, Balakrishnan N, Krishnamurthy K, Kirubakaran MG, Jacob CK: A prospective evaluation of leflunomide therapy for cytomegalovirus disease in renal transplant recipients. Transplant Proc 2005;37:4303-4305.

-35 Levi ME, Mandava N, Chan LK, Weinberg A, Olson JL: Treatment of multidrug-resistant cytomegalovirus retinitis with systemically administered leflunomide. Transpl Infect Dis 2006;8:38-43. 
Chon et al: Use of Leflunomide in Renal Transplant Recipients with GanciclovirResistant/Refractory Cytomegalovirus Infection

Table 1. Baseline characteristics of patients and CMV treatments before leflunomide therapy

\begin{tabular}{llllll}
\hline \multicolumn{1}{l}{ Patients } & & & \\
\cline { 2 - 6 } & 1 & 2 & 3 & 4 & 5 \\
\hline Age, years/ gender/race & $42 / \mathrm{M} / \mathrm{AA}$ & $34 / \mathrm{M} / \mathrm{H}$ & $43 / \mathrm{M} / \mathrm{AA}$ & $45 / \mathrm{M} / \mathrm{AA}$ & $51 / \mathrm{M} / \mathrm{AA}$ \\
Transplant date & $07 / 02 / 05$ & $08 / 12 / 08$ & $01 / 26 / 11$ & $12 / 06 / 02$ & $05 / 22 / 01$ \\
Transplant type & DDKTa & SPK & DDKT & DDKT & SPK \\
CMV D/R serostatus & D+/R+ & D+/R- & D+/R- & D+/R- & D+/R- \\
CMV viremia detection date & $08 / 09 / 05$ & $08 / 20 / 09$ & $06 / 22 / 11$ & $02 / 17 / 03$ & $08 / 11 / 03$ \\
CMV PPX & GCV (IV), VGCV & GCV (IV), VGCV & VGCV & VGCV & GCV (oral/IV) \\
LEF initiation date & $01 / 03 / 06$ & $01 / 22 / 10$ & $11 / 19 / 11$ & $05 / 08 / 03$ & $02 / 10 / 04$ \\
Antiviral agents before LEF (after PPX) & GCV (IV) FOS & GCV (IV) VGCV FOS & VGCV & GCV (IV) FOS & GCV (oral/IV) FOS \\
CMV resistance genotype & UL97 & None detected & UL97 & UL97 & Not done \\
\hline
\end{tabular}

DDKT = Deceased donor kidney transplant; LEF = leflunomide; FOS = foscarnet; PPX = prophylaxis; $\mathrm{M}=$ male; F = female; $\mathrm{AA}=\mathrm{African}$ American; $\mathrm{H}=$ Hispanic.

a Patient 1 had a retransplant of a previously transplanted allograft.

Table 2. Overview of literature on anti-CMV activity of leflunomide in kidney transplant recipients with either CMV infection or disease

\begin{tabular}{|c|c|c|c|c|c|c|c|}
\hline Authors [ref.] & $\begin{array}{l}\text { Patients, } \\
\mathrm{n}\end{array}$ & $\begin{array}{l}\text { CMV viremia } \\
\text { or disease (V/D) }\end{array}$ & $\begin{array}{l}\text { Anti-CMV therapy } \\
\text { before LEF }\end{array}$ & $\begin{array}{l}\text { Resistance } \\
\text { mutations }\end{array}$ & $\begin{array}{l}\text { Follow-up } \\
\text { duration, months }\end{array}$ & Outcome & $\begin{array}{l}\text { Time to viral } \\
\text { clearance }\end{array}$ \\
\hline Avery et al. [29] & 17 (3 K, 5 KP) & V (3), D (14) & GCV, FOS, CMVIg & $\begin{array}{l}\text { UL97 (7), } \\
\text { UL54 (2) }\end{array}$ & $7-36$ & $\begin{array}{l}\text { Viral clearance (9), } \\
\text { Transient response (5), } \\
\text { Failure (3) }\end{array}$ & $\begin{array}{l}0.4-5 \text { months } \\
\text { (median } 1.25 \text { ) }\end{array}$ \\
\hline Andrassy et al. [31] & 2 & $\mathrm{~V}(2)$ & GCV, FOS & UL97 (2) & $15-36^{+}$ & Viral clearance (2) & 6 weeks \\
\hline Ciszek et al. [32] & 1 & $\mathrm{~V}(1)$ & GCV, FOS, CMVIg & not done & $36+$ & Viral clearance (1) & 6 months \\
\hline John et al. [33] & 4 & $\mathrm{D}(4)$ & none & not done & $3-5$ & Viral clearance (4) & 1 month \\
\hline John et al. [34] & 17 & $\mathrm{~V}(7), \mathrm{D}(10)$ & GCV (3) & not done & $1-12$ & $\begin{array}{l}\text { Viral clearance (15), } \\
\text { Failure (2) }\end{array}$ & $\begin{array}{l}0.5-8 \text { months } \\
\text { (median 1.5) }\end{array}$ \\
\hline Levi et al. [35] ${ }^{\mathrm{a}}$ & 1 & D (colitis, retinitis) & GCV, FOS, CMVIg & $\begin{array}{l}\text { UL97 (1), } \\
\text { UL54 (1) }\end{array}$ & $12 \mathrm{~m}$ & Viral clearance (1) & 1 year \\
\hline
\end{tabular}

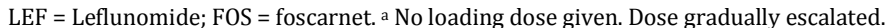


Chon et al.: Use of Leflunomide in Renal Transplant Recipients with GanciclovirResistant/Refractory Cytomegalovirus Infection
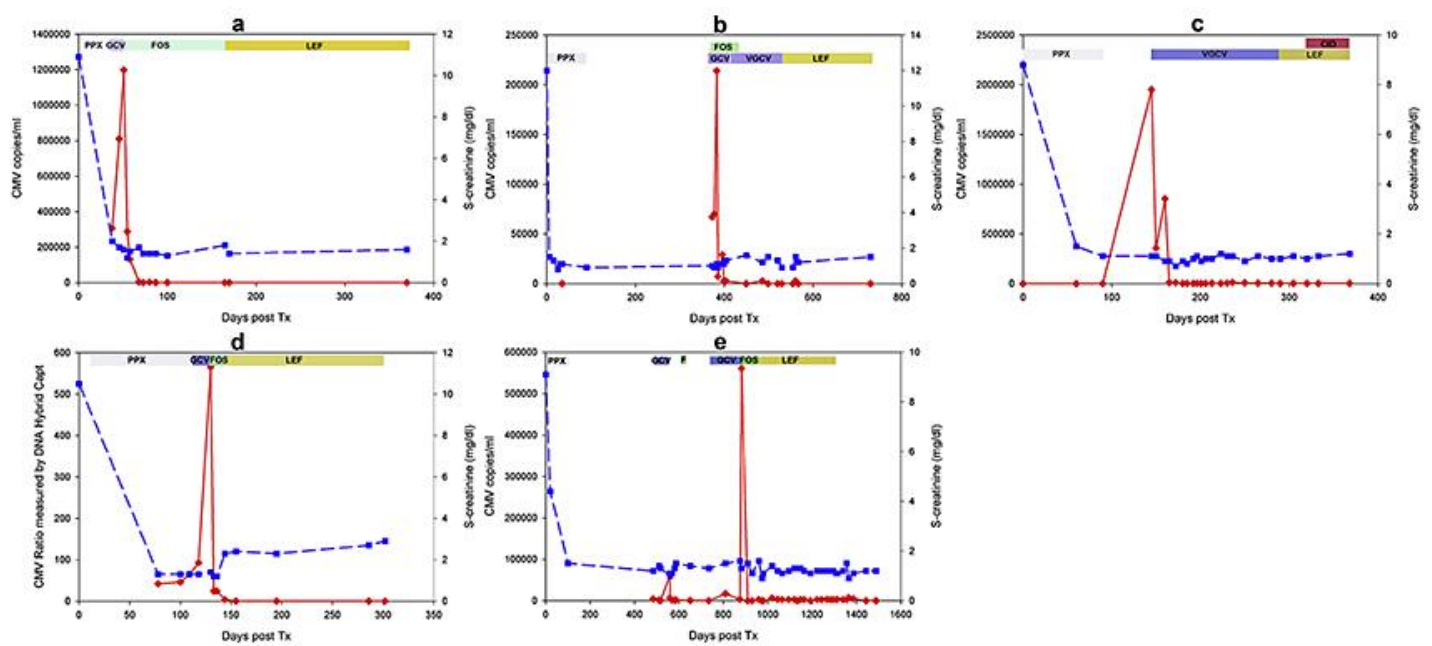

Fig. 1. Kinetics of viral load (red solid line) and Scr (blue dashed line) in 5 patients with CMV viremia after antiviral prophylaxis treated with leflunomide and other antiviral agents. The horizontal axis in each frame shows the time course in days after renal transplant (Tx). The duration of antiviral prophylaxis and therapy with different antiviral agents is indicated by horizontal bars on the top of each frame. PPX = Prophylaxis (gray bars); GCV/VGCV (purple bars); LEF = leflunomide (orange bars); FOS = foscarnet (green bars); CID = brincidofovir (red bar). 